Article

\title{
Evaluation of Tuber Yield and Marketable Quality of Newly Developed Thirty-Two Potato Varieties Grown in Three Different Ecological Zones in South Korea
}

\author{
Jahirul Islam ${ }^{1,2,+} \oplus^{\oplus}$, Sun Phil Choi ${ }^{1,+}$, Obyedul Kalam Azad ${ }^{1}{ }^{\oplus}$, Ji Woong Kim ${ }^{1, \dagger}$ \\ and Young-Seok $\operatorname{Lim}^{1, *}$ \\ 1 Department of Bio-Health Technology, Kangwon National University, Chuncheon 24341, Korea; \\ jahirulislam213@gmail.com (J.I.); goodneed@ht-calbee.co.kr (S.P.C.); azadokalam@gmail.com (O.K.A.); \\ jiwoongki@naver.com (J.W.K.) \\ 2 Physiology and Sugar Chemistry Division, Bangladesh Sugarcrop Research institute, \\ Ishurdi 6620, Pabna, Bangladesh \\ * Correspondence: potatoschool@kangwon.ac.kr; Tel.: +82-10-8896-7658 \\ $+\quad$ These authors contribute equally.
}

Received: 16 June 2020; Accepted: 31 July 2020; Published: 3 August 2020

\begin{abstract}
The yield and quality of potato in South Korea vary with different environmental conditions and all induced varieties do not perform well in every location. There are many suggested reasons for this problem; they include soil topography, temperature, rainfall pattern, etc. This study focused on finding certain potato genotypes based on high yield and quality (marketable rate, uniformity, less physiological disorders, resistance to diseases), and suitability for processing in three agro-ecological regions in South Korea. Thirty-two potato genotypes were cultivated in three regions i.e., Chuncheon (low altitude), Yang-gu (middle altitude), and Pyeong-chang (alpine), along with three major cultivars (Atlantic, Shepody, and Superior) as control. All the potato lines were evaluated for three consecutive years. The results showed that a higher tuber yield was obtained from the genotypes Gangwon Valley, Valley 11, Valley 13, and Valley 92 in Chuncheon; while Valley 13, Valley 43, and Valley 92 in Yang-gu; and Valley 43, Gui Valley and Valley 92 in Pyeong-chang region with a high marketable quality, and lower infection rates and physiological disorders. The results also showed that higher chip lightness was manifested by the genotypes Juice Valley, Gangwon Valley, Rose Valley, Valley 43, and Valley 91 among the high yielding genotypes. Besides, Pyeong-chang (alpine), a high-altitude region with longer maturation time was found more suitable for potato cultivation, especially for higher tuber yield and higher quality products for potato chip processing.
\end{abstract}

Keywords: potato variety; ecological region; yield; marketability; disease resistance; specific gravity; chip lightness

\section{Introduction}

Potatoes (Solanum tuberosum L.) belong to the Solanaceae family, which originated in South America, specifically in the Andean mountain region [1]. It is now the fourth most important world food crop after wheat, rice, and maize; and second in South Korea [2]. Potatoes serve as an important source of carbohydrates, proteins, vitamins (vitamin B and C), and minerals [3-9]. It is currently being cultivated in over 100 countries and feeds more than a billion people worldwide [10]. The total world potato production was estimated at 368.25 million metric tons in 2018 [11]. Hence, enhancing the productivity of this root vegetable may be a key tool in fulfilling the nutritional requirements of the rising global population [12]. 
Potato quality is an important aspect with regards to marketability. It can be categorized as "external quality", which includes skin color, eye depth, tuber size, shape, etc.; "internal quality", which describes its culinary and nutritional properties, and processing quality and after-cooking properties [13]. Quality also indicates if the vegetable is free from diseases, and physical and physiological disorders, which greatly depends on both genetical and environmental components.

To meet the demands of farmers, industry, and consumers, the focus of breeding is to develop improved varieties, which combine higher yield, short duration, resistance to abiotic and biotic stress, and are suitable for table and processing purposes [14]. The most important concern for the potato chip industry is color, because if a desirable color is not obtained, the relative importance of the remaining traits is diminished. Quality traits important for cultivars used in potato chips manufacturing include high dry matter, low sugar, and free from defects [15]. Chip defects can also result from several external and internal problems, including growth cracks, hollow heart, heat necrosis, mechanical injury, greening, and tuber rot. Therefore, the identification and development of potatoes producing less reducing sugar (RS) is becoming a priority in several potato breeding programs $[16,17]$. As the potato processing industry is emerging as a fast-growing sector in different countries, potatoes must fulfill certain quality attributes, such as low RS and high dry matter (DM) content [18]. The aim of this study was to find high yielding potato lines for processing, those that are resistant to diseases and physiological disorders. The objective was to find a suitable potato variety that grows under different climatic conditions for potato breeding purposes, especially targeting chip processing.

\section{Materials and Methods}

The study was conducted at three different agro-ecological regions in South Korea: Chuncheon (low altitude), Yang-gu (middle altitude), and Pyeong-chang (alpine). The planting season was summer, the main potato growing season for all three areas with a high occurrence of rainfall. It starts from late March to early April for the low altitude Chuncheon region and mid-April to early May for the other two regions (Supplementary Figure S1). Potato maturation time is a little bit high in the alpine region (100-120 days after planting) compared to the middle and low altitude areas (90-110 days after planting).

Potatoes are generally considered highly tolerant to acid soil [19]. Our experiment sites are acidic in nature, with $\mathrm{pH}$ values ranging between $4.48-5.85$, while organic matter was $>1.5 \%$ in the topsoil (Supplementary Table S1). Thirty-two potato genotypes (Table 1) were received from the Center for the Korea Potato Genetic Resources and cultivated in three different regions with three major cultivars, Atlantic, Shepody, and Superior, as the control. All potato lines were evaluated (100 days) in three different regions: Chuncheon, Yang-gu, Pyeong-chang in three consecutive year (2016 to 2018) of which each year's data was treated as one replication. To screen the breeding materials suitable for processing quality, tubers were evaluated for specific gravity and glucose content.

Table 1. List of 35 newly developed valley potato lines used in this study and their parental background.

\begin{tabular}{lccll}
\hline Lines & Abbreviation & Ploidy & Mother & Father \\
\hline Gogu Valley & S1 & $4 \mathrm{X}$ & Shepody & A8812-3 \\
Juice Valley & S2 & $4 \mathrm{X}$ & A90356-1R & Co86218-2R \\
Valley 3 & S3 & $4 \mathrm{X}$ & Unknown & Unknown \\
Early Valley & S4 & $4 \mathrm{X}$ & Sunscrisp & A87109-10 \\
Summer Valley & S5 & $4 \mathrm{X}$ & Atlantic & DG55 \\
Valley 6 & S6 & $4 \mathrm{X}$ & Unknown & Unknown \\
Valley 7 & S7 & $4 \mathrm{X}$ & Unknown & Unknown \\
Winter Valley & S8 & $4 \mathrm{X}$ & Sunscrisp & A87109-10 \\
Taedong Valley & S9 & $4 \mathrm{X}$ & W870 & A88431-1 \\
\hline
\end{tabular}


Table 1. Cont.

\begin{tabular}{|c|c|c|c|c|}
\hline Lines & Abbreviation & Ploidy & Mother & Father \\
\hline Gangwon Valley & S10 & $4 X$ & NDO1496-1 & A90359-7 \\
\hline Valley 11 & S11 & $4 X$ & Unknown & Unknown \\
\hline Valley 12 & S12 & $4 X$ & Unknown & Unknown \\
\hline Valley 13 & S13 & $4 X$ & Atlantic & Superior \\
\hline Valley 15 & S14 & $4 X$ & Unknown & Unknown \\
\hline Valley 17 & S15 & $4 X$ & Chipeta & A90359-7 \\
\hline Valley 19 & S16 & $4 X$ & Cs7232-4 & Unknown \\
\hline Bora Valley & S17 & $4 X$ & A87sp $\times 14-4$ & Gurmeys purple \\
\hline Rose Valley & S18 & $4 X$ & $8902 \times$ Norchip & P1323471A \\
\hline Stick Valley & S19 & $4 X$ & $7389 \times$ Superior & B1066-1 \\
\hline Valley 31 & S20 & $4 X$ & Unknown & Unknown \\
\hline Valley 32 & $\mathrm{~S} 21$ & $4 X$ & W870 & A88431-1 \\
\hline Giant Valley & $\mathrm{S} 22$ & $4 X$ & 6545B0850-4 & В0975-1 \\
\hline Purple Valley & $\mathrm{S} 23$ & $4 X$ & 6545B0850-4 & B0975-1 \\
\hline Valley 43 & S24 & $4 X$ & Unknown & Unknown \\
\hline Valley 45 & $\mathrm{~S} 25$ & $4 X$ & Unknown & Unknown \\
\hline Valley 47 & S26 & $4 X$ & A83359-5R & A89655-5DY \\
\hline Valley 52 & $\mathrm{~S} 27$ & $4 X$ & Unknown & Unknown \\
\hline Rchip Valley & $\mathrm{S} 28$ & $4 X$ & A90356-1R & Co86218-2R \\
\hline Valley 89 & S29 & $4 X$ & Unknown & Unknown \\
\hline Gui Valley & $\mathrm{S} 30$ & $4 X$ & ND2471-8 & Cona \\
\hline Valley 91 & S31 & $4 X$ & Unknown & Unknown \\
\hline Valley 92 & S32 & $4 X$ & Unknown & Unknown \\
\hline Atlantic & S33 & $4 X$ & Wauseon & B5141-6 \\
\hline Shepody & $\mathrm{S} 34$ & $4 X$ & Bake-King & F58050 \\
\hline Superior & S35 & $4 X$ & B96-56 & M59-44 \\
\hline
\end{tabular}

\subsection{Agronomical Data}

To obtain agronomical data, tuber from one line was harvested for each variety. Tuber yield was gained by measuring total tuber weight divided by the number of plants. On the other hand, up to $5 \mathrm{~cm}$ in diameter of tuber was calculated to estimate the rate of marketable tuber. Rate of marketable tuber $(\%)=$ number of marketable tuber/total number $\times 100$. Rate of cracking and rate of uniformity were done by the following formulae:

Rate of cracking tuber $(\%)=$ number of cracking tuber/total tuber number $\times 100$.

Rate of tuber uniformity $(\%)=$ uniformed tuber number/total tuber number $\times 100$.

\subsection{Common Scab Infected Tuber}

All tubers from each line were examined and percentage of surface area with scab lesion was estimated with Horsfall-Barratt rating scale [20], and then scab severity of each line was calculated through the following expression:

$$
\text { Scab severity }=\frac{\sum \mathrm{f}_{\mathrm{i}}^{\mathrm{L}} \mathrm{Kj}^{\mathrm{Y}}}{\text { Total No. of tubers } \times 5} \times 100
$$

L: the number of tuber scored as that rating

Y: $\quad$ rating (from 1 to 5 ) 


\subsection{Appearance Rate of Physiological Disorder}

To estimate the rate of internal brown spots and hollow heart symptoms of the tuber, samples were collected from each line at the harvest and calculated by following formula:

Tuber Disorder rate $(\%)=$ number of abnormal tuber/total tuber number $\times 100$

\subsection{Specific Gravity Measurement}

Five (80-130 g) tubers from each potato clone were taken from each line after harvest and cured for two weeks before analysis. The tubers were all synchronized by weight to ensure uniformity per clone. Specific gravity of tuber was measured by using the following formula:

Specific Gravity = weight in air/(weight in air - weight in water)

\subsection{Measurement of Chip Color}

Medium size tubers (5-10 $\mathrm{cm}$ in diameter) were collected from each potato line and cured at about $15^{\circ} \mathrm{C}$ and $95 \%$ relative humidity for two weeks before chip processing. Lightness was measured on creating a chip using bean oil at $180^{\circ} \mathrm{C}$.

\subsection{Analysis of Reducing Sugar}

Glucose content in the tuber were measured at the time of preconditioning. First, $1 \mathrm{~g}$ of 3,5-dinitrosalicylic acid was dissolved in $20 \mathrm{~cm}^{3}$ of $2 \mathrm{M} \mathrm{NaOH}$ solution and $50 \mathrm{~cm}^{3}$ water. Then, $30 \mathrm{~g}$ Rochelle Salt (Na-K-tartrate) was added and made up to $100 \mathrm{~cm}^{3}$ with distilled water. The solution was protected from $\mathrm{CO}_{2}$ in well-filled bottles. The final volume was made up to $2000 \mathrm{~mL}$ using a measuring cylinder and stored in dark brown bottles. The samples were obtained by a $4 \mathrm{~mm}$ cork borer pushed through the center of each tuber, about halfway between the ends and the core. Each sample was dropped into a test tube containing $1 \mathrm{~mL}$ of water and $2 \mathrm{~mL}$ of reagent and the tubes were kept boiling at $94{ }^{\circ} \mathrm{C}$ in a water bath for $8 \mathrm{~min}$. After cooling, $2 \mathrm{~mL}$ of deionized water was added to the test tubes and absorbance was measured at $570 \mathrm{~nm}$ by spectrophotometer. The value of extinct was substituted to a regression formula and glucose content was calculated using the following expression:

$$
\begin{aligned}
& \text { Glucose weight }(\mathrm{mg})=\mathrm{ABS} \times 1.845-0.092 \\
& \text { Glucose content }(\%)=\text { glucose weight }(\mathrm{mg}) \times 100 / \text { weight of sample }(\mathrm{mg})
\end{aligned}
$$

\section{Statistical Analysis}

All data were expressed as the mean of triplicate measurements. The obtained results were compared among the genotypes in different ecological regions to observe significant differences at the level of 5\%. All graphs were prepared by GraphPad prism 5 (San Diego, CA 92108, USA) and expressed as mean \pm standard error mean (SEM). Duncan's multiple range test (DMRT) was done by Statistix 10 (Tallahassee, FL 32312, USA).

\section{Results and Discussion}

\subsection{Tuber Yield and Quality}

Significant variations $(P<0.05)$ in tuber yield were observed among the cultivars in different locations. Tuber yield ranged from 335-1530 (g/plant), 315-1400 (g/plant), and 450-1500 (g/plant) in region 1 (Chuncheon), region 2 (Yang-gu), and region 3 (Pyeong-chang), respectively (Figure 1). The potato lines S13, S32, S11, and S10 performed better than all of the three control cultivars $(P<0.05)$ in Chuncheon; S32 and S24 were found better than all control cultivars in Yang-gu, while S4 and S13 
showed similar results as that of Atlantic (1110 g/plant). Similarly, S32, S4, S24, and S30 performed better $(P<0.05)$ than all cultivars in the Pyeong-chang area.

- Chun-cheon \ Yang-gu I Pyeong-chang

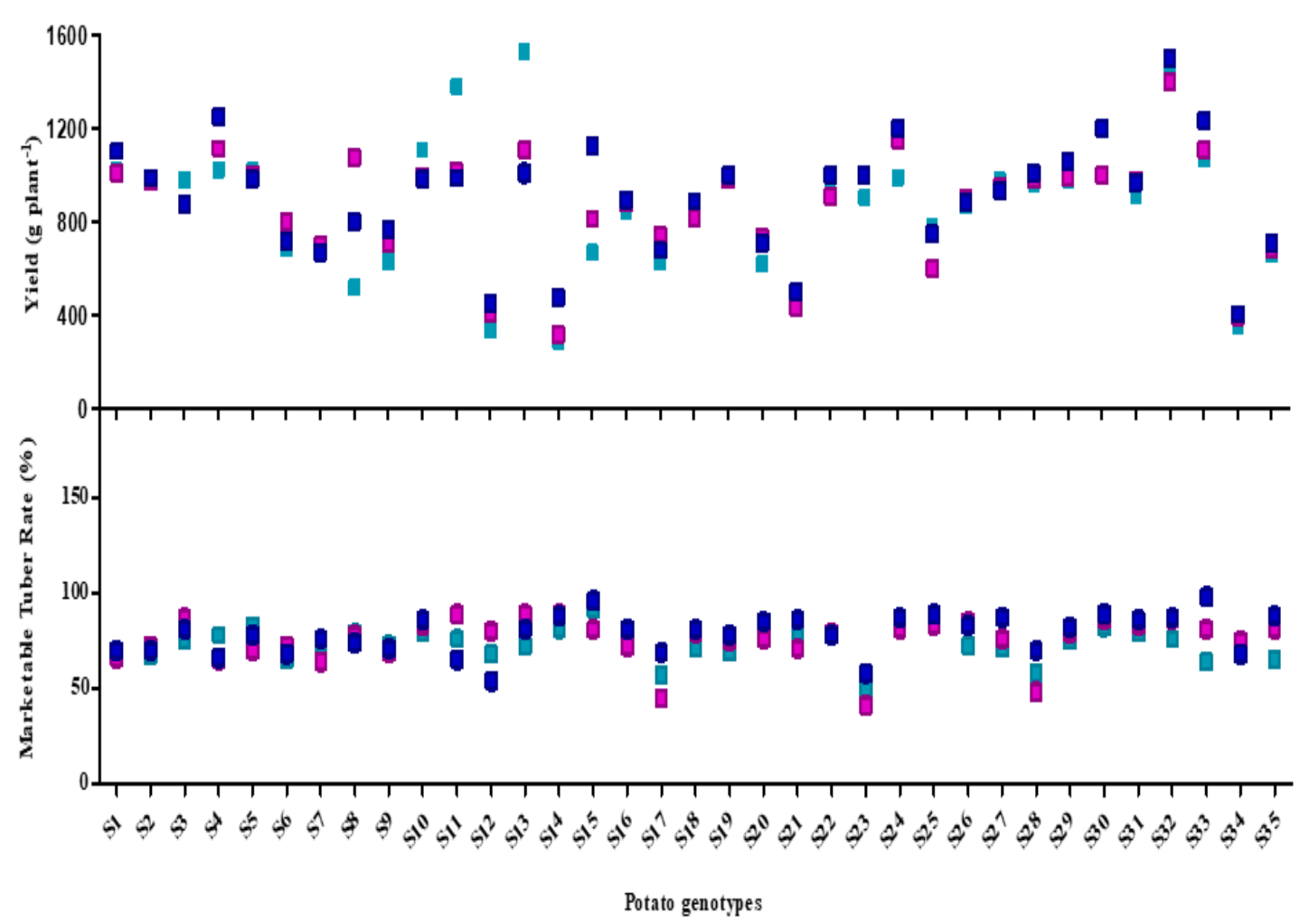

Figure 1. Average tuber yield (g/plant) and marketable tuber rate ( $>5 \mathrm{~cm}$ in diameter; $\%)$ of 35 potato lines grown in three agro-ecological regions: Chuncheon (low altitude), Yang-gu (middle altitude), and Pyeong-chang (alpine) in South Korea. The bars represent standard error mean (SEM).

The differences between tuber initiation and crop senescence, along with tuber bulking rate, determines the total tuber yield of potato crops [21]. The total number of high yielding potato (over $1000 \mathrm{~g} /$ plant) cultivars were found in Pyeong-chang (11), followed by Yang-gu (10) and Chuncheon (7). Higher maturation time with high altitude in Pyeong-chang (Alpine) might be the reason for its differentiation from the other two areas in respect to tuber yield. The results are also in agreement with a report by Patel et al. [22] on the relationship of the number of tubers per plant and the size of tubers with low temperature. Sojka et al. [23] reported that zone subsoiling has a tremendous effect on potato tuber formation because of its soil compactness and reservoir tillage quality. Our study assumes that region 3 (Pyeong-chang) has favorable soil type and compactness for potato production (Table S1), with low temperature, rainfall, and sunshine during maturing time (Figure S1). Maximum tuber yield in the Pyeong-chang region might be due to a greater number of tubers and tuber weight in comparison to other regions [24].

Marketable tuber yield determines the economic value of tuber production [25]. In the present experiment, marketable tuber rate varied with respect to varietal and environmental differences. Marketable tuber rate ranged from $49-92 \%, 41-89 \%$, and $54-96 \%$ in Chuncheon, Yang-gu, and Pyeong-chang, respectively (Figure 1). Among the 32 evaluated potato lines, the highest marketable tuber rate was obtained from S15 (92\%) in Chuncheon (Region 1); in addition, 22 specific clones were found to be significantly better $(P<0.05)$ than the three control cultivars.

In region 2 (Yang-gu), S11, S13, S14, and S3 gave a higher marketable yield, compared to all other clones, including 3 control cultivars with $P<0.05$, while 7 other clones were also found to be 
better $(P<0.05)$ than the 3 control varieties. On the other hand, in the case of region 3 (Pyeong-chang), S15 showed the highest marketable tuber rate $(96 \%)$ as region 1 (Chuncheon), and it was significantly higher than Shepody and Superior. Besides, except for S4, S11, S12, and S23, all genotypes were recorded with a higher marketable yield in Pyeong-chang. The number of cultivars with high marketable rate $(>80 \%)$ was found higher in Pyeong-chang (11), followed by Yang-gu (13) and Chuncheon (6). A higher maturation time with high altitude in Pyeong-chang (Alpine) might be a reason for its differences from the other two areas in respect to high marketable rate-tuber yield. Potato line S15 also produced the highest average marketable tuber rate (90\%) in all three regions. Similarly, S14 (86\%), S30 (86\%), S25 $(85 \%)$, and S24 $(83 \%)$ showed better average performance $(P<0.05)$ in all three regions.

The results showed that most of the genotypes produce uniform tubers (except S6, S7, S11, S17, S18, and S20), compared to the control variety Atlantic (78\%) with $P<0.05$ (Figure 2). Similar trends were also observed for Shepody and Superior in Chuncheon region. In the case of Yang-gu, the clones S6, S8, S10, S11, S14, S15, S17, S21, and S26 performed poorly $(P<0.05)$, compared to the control variety Atlantic (78\%). On the other hand, all tubers, except S10, S11, S14, and S17 were found to be better $(P<0.05)$ than the others, compared to control variety Atlantic $(76 \%)$ in Pyeong-chang; whereas average tuber uniformity for most of the lines (except S11, S17, and S26) was found to be higher than the control line Atlantic (77\%) and lower than that of the control line Shepody (91\%). In a previous study, it was suggested that both yield, and marketable quality have a positive correlation with higher altitude and presence of higher magnesium in soil in different regions of Europe [26]. It was also stated that a shorter growing period is responsible for delayed tuber growth and reduction of assimilates allocation in the Mediterranean area [26,27]. Along with a high concentration of magnesium in soil and longer maturation time, Pyeong-chang (Alpine) manifested higher yield and marketable quality of tuber compared to other regions in the present study, clearly complying with previous findings.

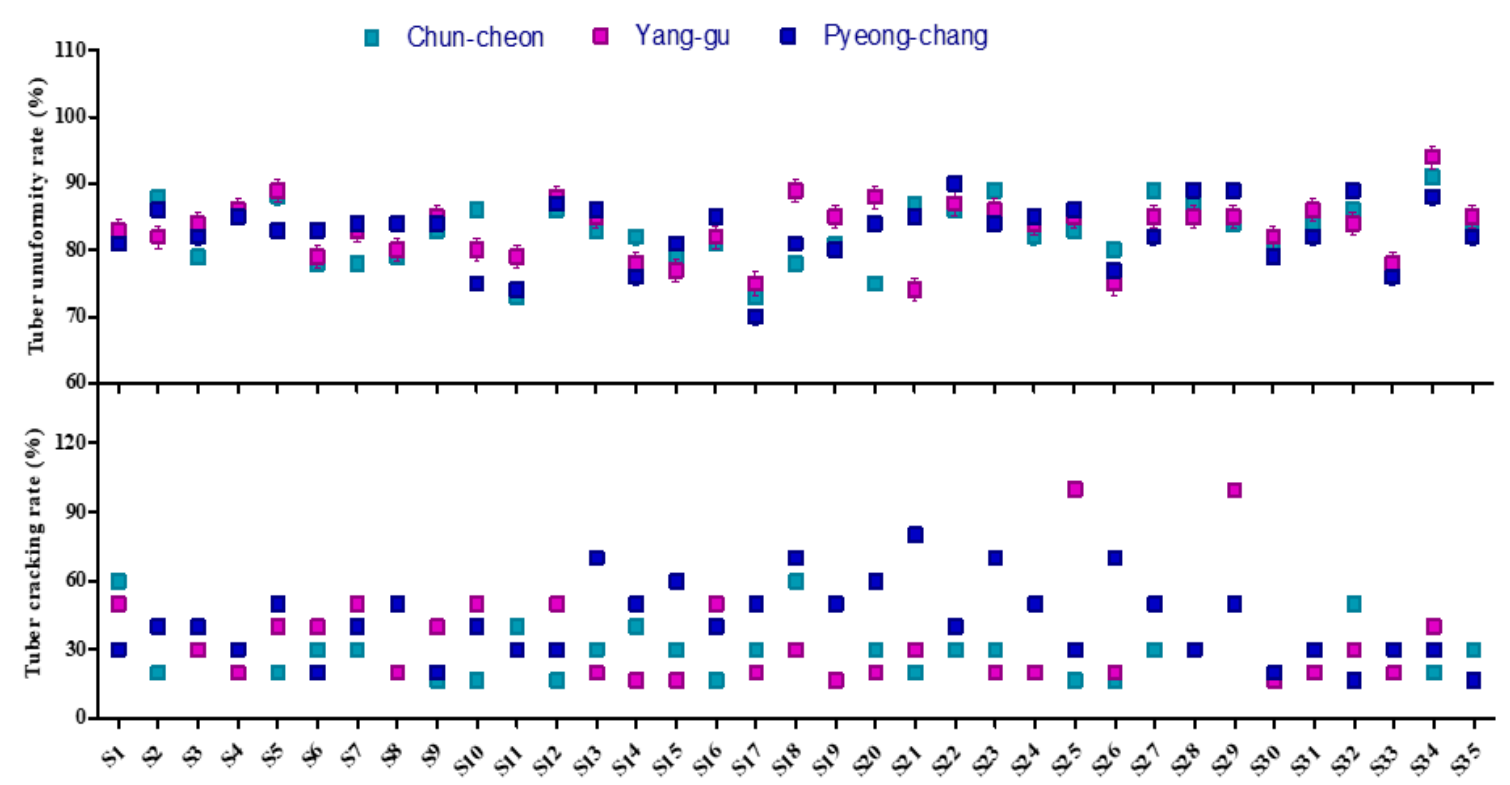

Figure 2. Tuber uniformity rate (\%) and tuber cracking rate (\%) of 35 potato lines grown in three agro-ecological regions: Chuncheon (low altitude), Yang-gu (middle altitude), and Pyeong-chang (alpine) in South Korea. The bars represent standard error mean (SEM).

\subsection{Tuber Cracking Rate (\%)}

The potato clones varied with respect to tuber cracking rate. Tuber cracking rate ranged from $16.67-60 \%, 16.67-100 \%$, and $16.67-80 \%$ in region 1 (Chuncheon), region 2 (Yang-gu), and region 3 (Pyeong-chang), respectively (Figure 2). In Chuncheon, the potato lines S2, S4, S5, S8, S9, S10, S12, S16, S21, S25, S26, and S30 produced minimum tuber cracking $(\leq 20 \%)$, which is less than the control line Superior and equal to Atlantic and Shepody; despite significant differences. On the other hand, 
potato lines S1 and S18 produced a higher percentage of cracking tuber $(60 \%)$, compared to all three control cultivars with $(P<0.05)$. In region 2, two specific clones-S25 and S29-were found with $100 \%$ cracking, which is significantly higher $(P<0.05)$ than the three control cultivars. On the other hand, the potato lines S6, S9, S30, and S32 were found to be strong against tuber cracking $(\leq 20 \%)$ in region 3 , compared to Atlantic and Shepody. In case of the average of three regions, potato lines S4 and S30 produced minimum cracking, compared to Shepody. Comparatively, a higher number of cultivars (15) with high cracking rate $(\geq 50 \%)$ was observed in the alpine area, followed by middle altitude $(7)$ and low altitude (6); however, its severity can still be considered low. Generally, growth cracks develop in the tuber enlargement stage as a consequence of irregular irrigation, overdose of nitrogen, and nutrient imbalance (like boron deficiency) [28,29]. Although the present research did not clearly identify the reason for high cracking rate in the Pyeong-chang area, uneven moisture and temperature distribution in the alpine region [30] might play an important part.

\subsection{Potato Common Scab Infected Rate (\%) and Potato Common Scab Severity (\%)}

Although common scab disease, characterized by raised or pitted scabby lesions on the tuber surface, has no effect on potato yield, it has a negative impact on marketability [31]. In the present experiment, potato clones varied with respect to common scab infection rate (\%) and severity (\%) at different locations. The results (Figure 3) show that the lowest infected rate was $52.6 \%$ and highest was $100 \%$ in region 1 (Chuncheon); 29.4 and 100\% in region 2 (Yang-gu), and 61.5 and $98.4 \%$ in region 3 (Pyeong-chang). Eleven clones were found with a significantly lower $(P<0.05)$ infection rate than the three control cultivars in region 1, with 15 cultivars from region 2 and 2 cultivars from region 3, respectively.

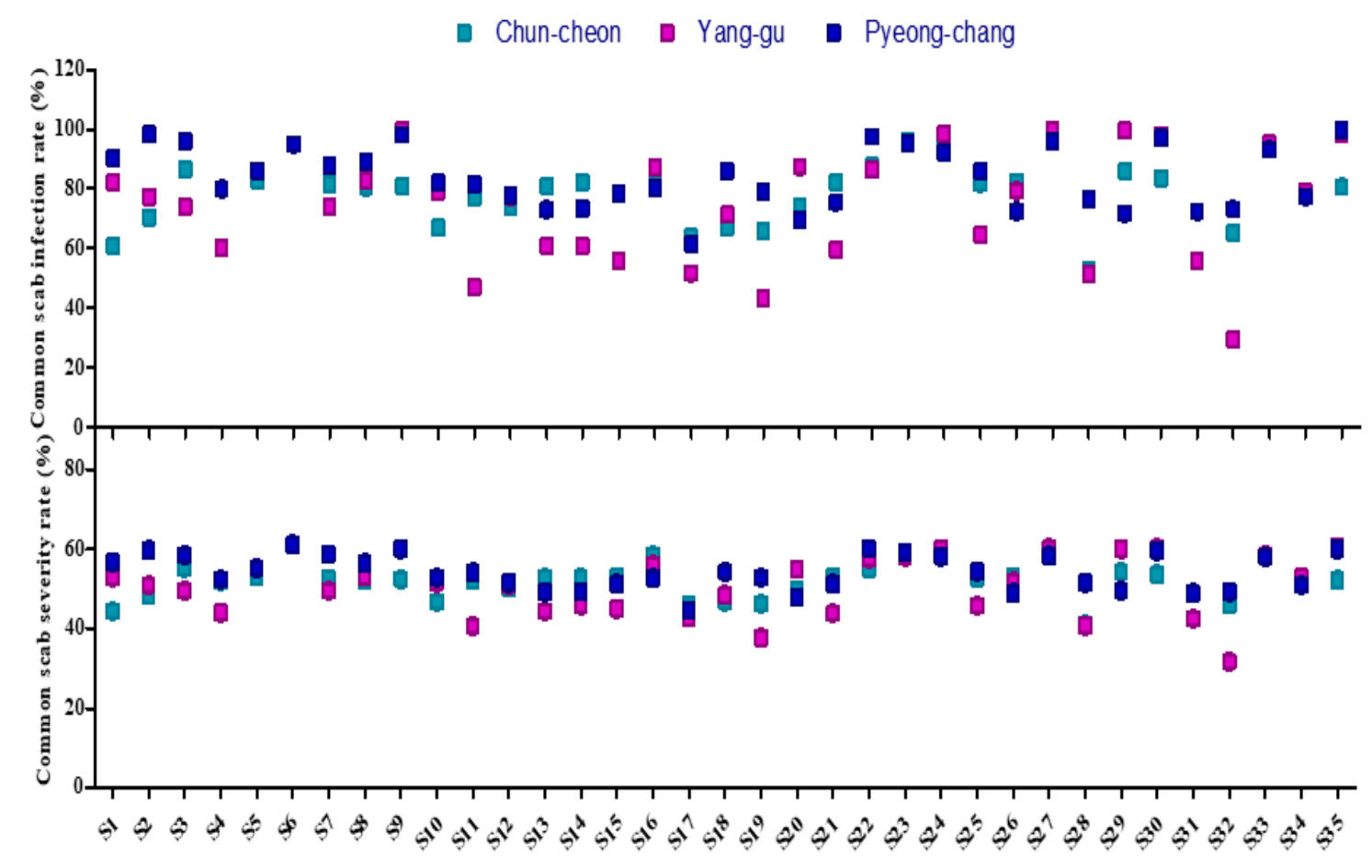

Figure 3. Tuber common scab infection rate (\%) and tuber common scab severity rate (\%) of 35 potato lines grown in three agro-ecological regions: Chuncheon (low altitude), Yang-gu (middle altitude), and Pyeong-chang (alpine) in South Korea. The bars represent standard error mean (SEM).

We also observed a different range of common scab severity in three different locations. Common scab severity ranged from $41.05-61.2 \%, 31.76-61.2 \%$, and $44.62-61.2 \%$ in Chuncheon, Yang-gu, and Pyeong-chang, respectively (Figure 3). In Chuncheon (region 1), four specific clones-S6 $(61.2 \%)$, S16 (58.55\%), S23 (58.53\%), and S24 (58.21\%) -were found with higher scab severity than two 
control varieties, Shepody and superior $(P<0.05)$. The clone S6, S30, S27, S9, S24, and S29 showed higher severity in Yang-gu compared to Atlantic and Shepody. On the other hand, in region 3, highest severity was found in clone $\mathrm{S6}$, compared to all three control cultivars $(P<0.05)$. A similar trend was observed from S22, S9, S2, S30, S23, S7, S3, S27, and S24 in the same area. It has been stated that environmental variables or differences in pathogen populations may drive the instability or resistance among potato cultivars and clones-resistance in one program may often lead to susceptibility in other breeding programs when they are released [32]. Numerous studies have stated that a rise of soil $\mathrm{pH}$ from 4.0 to 7.0 can increase both the number of tubers infected by common scab and the area of tuber surface damage [33-35]. In our study, both common scab infection and severity rate were found to be lower in Yang-gu, a middle altitude area with lower $\mathrm{pH}$, compared to the other two areas. Therefore, this finding also supports infection and severity differences among the potato clones in three different locations of the present study due to their differences in soil characteristics.

\subsection{Internal Brown Spot Rate (\%)}

Internal brown spot in potato is a physiological disorder characterized by internal necrosis of medullary tissue. It is relatively common in potato tubers grown in sandy soils. The presence of this necrotic lesion greatly reduces the quality of potato chips and culinary value of the tubers because of the presence of the brown discolored, fibrous-like masses of cells [36].

The occurrence of internal brown spots varied with respect to cultivars in our study. The highest internal brown spots was observed in region 1 (Chuncheon) from the potato line S27 (13.33\%), followed by S3, S4, S7, S10, S11, S14, S15, S20, S23, S25, and S28 (6.67\% for all) (Table 2). However, it can still be considered a comparatively low rate of occurrence.

Table 2. Internal brown spot (IBS) (\%) and hollow heart occurred rate (HHR) (\%) of 35 potato lines grown in three different agro-ecological regions in South Korea.

\begin{tabular}{ccccccccc}
\hline \multirow{2}{*}{ Lines } & \multicolumn{2}{c}{ Region 1 } & \multicolumn{2}{c}{ Region 2 } & \multicolumn{2}{c}{ Region 3 } & \multicolumn{2}{c}{ Average } \\
\cline { 2 - 8 } & IBS & HHR & IBS & HHR & IBS & HHR & IBS & HHR \\
\hline S1 & $0 \mathrm{a} *$ & $6.67 \mathrm{~b}$ & $0 \mathrm{a}$ & $0 \mathrm{a}$ & $0 \mathrm{a}$ & $6.67 \mathrm{bc}$ & 0 & 4.44 \\
S2 & $0 \mathrm{a}$ & $6.67 \mathrm{~b}$ & $13.33 \mathrm{a}$ & $0 \mathrm{a}$ & $0 \mathrm{a}$ & $0 \mathrm{a}$ & 4.44 & 2.22 \\
S3 & $6.67 \mathrm{a}$ & $0 \mathrm{~b}$ & $6.67 \mathrm{a}$ & $6.67 \mathrm{a}$ & $6.67 \mathrm{a}$ & $0 \mathrm{a}$ & 6.67 & 2.22 \\
S4 & $6.67 \mathrm{a}$ & $3.33 \mathrm{~b}$ & $13.33 \mathrm{a}$ & $0 \mathrm{a}$ & $0 \mathrm{a}$ & $0 \mathrm{a}$ & 6.67 & 1.11 \\
S5 & $0 \mathrm{a}$ & $0 \mathrm{~b}$ & $13.33 \mathrm{a}$ & $0 \mathrm{a}$ & $0 \mathrm{a}$ & $0 \mathrm{a}$ & 4.44 & 0 \\
S6 & $0 \mathrm{a}$ & $6.67 \mathrm{~b}$ & $0 \mathrm{a}$ & $0 \mathrm{a}$ & $0 \mathrm{a}$ & $6.67 \mathrm{bc}$ & 0 & 4.44 \\
S7 & $6.67 \mathrm{a}$ & $0 \mathrm{~b}$ & $0 \mathrm{a}$ & $0 \mathrm{a}$ & $6.67 \mathrm{a}$ & $0 \mathrm{a}$ & 4.44 & 0 \\
S8 & $0 \mathrm{a}$ & $3.33 \mathrm{~b}$ & $6.67 \mathrm{a}$ & $0 \mathrm{a}$ & $0 \mathrm{a}$ & $0 \mathrm{a}$ & 2.22 & 1.11 \\
S9 & $0 \mathrm{a}$ & $0 \mathrm{~b}$ & $0 \mathrm{a}$ & $0 \mathrm{a}$ & $0 \mathrm{a}$ & $6.67 \mathrm{bc}$ & 0 & 2.22 \\
S10 & $6.67 \mathrm{a}$ & $0 \mathrm{~b}$ & $0 \mathrm{a}$ & $0 \mathrm{a}$ & $6.67 \mathrm{a}$ & $6.67 \mathrm{bc}$ & 4.44 & 2.22 \\
S11 & $6.67 \mathrm{a}$ & $0 \mathrm{~b}$ & $0 \mathrm{a}$ & $0 \mathrm{a}$ & $0 \mathrm{a}$ & $0 \mathrm{a}$ & 2.22 & 0 \\
S12 & $0 \mathrm{a}$ & $0 \mathrm{~b}$ & $6.67 \mathrm{a}$ & $0 \mathrm{a}$ & $0 \mathrm{a}$ & $0 \mathrm{a}$ & 2.22 & 0 \\
S13 & $0 \mathrm{a}$ & $0 \mathrm{~b}$ & $6.67 \mathrm{a}$ & $0 \mathrm{a}$ & $0 \mathrm{a}$ & $0 \mathrm{a}$ & 2.22 & 0 \\
S14 & $6.67 \mathrm{a}$ & $0 \mathrm{~b}$ & $6.67 \mathrm{a}$ & $0 \mathrm{a}$ & $6.67 \mathrm{a}$ & $0 \mathrm{a}$ & 6.67 & 0 \\
S15 & $6.67 \mathrm{a}$ & $0 \mathrm{~b}$ & $6.67 \mathrm{a}$ & $0 \mathrm{a}$ & $6.67 \mathrm{a}$ & $0 \mathrm{a}$ & 6.67 & 0 \\
S16 & $0 \mathrm{a}$ & $0 \mathrm{~b}$ & $6.67 \mathrm{a}$ & $6.67 \mathrm{a}$ & $0 \mathrm{a}$ & $0 \mathrm{a}$ & 2.22 & 2.22 \\
S17 & $0 \mathrm{a}$ & $0 \mathrm{~b}$ & $0 \mathrm{a}$ & $0 \mathrm{a}$ & $6.67 \mathrm{a}$ & $0 \mathrm{a}$ & 2.22 & 0 \\
S18 & $0 \mathrm{a}$ & $6.67 \mathrm{~b}$ & $13.33 \mathrm{a}$ & $0 \mathrm{a}$ & $0 \mathrm{a}$ & $0 \mathrm{a}$ & 4.44 & 2.22 \\
S19 & $0 \mathrm{a}$ & $0 \mathrm{~b}$ & $0 \mathrm{a}$ & $0 \mathrm{a}$ & $0 \mathrm{a}$ & $0 \mathrm{a}$ & 0 & 0 \\
S20 & $6.67 \mathrm{a}$ & $0 \mathrm{~b}$ & $6.67 \mathrm{a}$ & $0 \mathrm{a}$ & $0 \mathrm{a}$ & $0 \mathrm{a}$ & 4.44 & 0 \\
S21 & $0 \mathrm{a}$ & $0 \mathrm{~b}$ & $6.67 \mathrm{a}$ & $0 \mathrm{a}$ & $0 \mathrm{a}$ & $0 \mathrm{a}$ & 2.22 & 0 \\
S22 & $0 \mathrm{a}$ & $0 \mathrm{~b}$ & $0 \mathrm{a}$ & $0 \mathrm{a}$ & $0 \mathrm{a}$ & $0 \mathrm{a}$ & 0 & 0 \\
S23 & $6.67 \mathrm{a}$ & $0 \mathrm{~b}$ & $0 \mathrm{a}$ & $0 \mathrm{a}$ & $6.67 \mathrm{a}$ & $0 \mathrm{a}$ & 4.44 & 0 \\
\hline
\end{tabular}


Table 2. Cont.

\begin{tabular}{ccccccccc}
\hline \multirow{2}{*}{ Lines } & \multicolumn{2}{c}{ Region 1 } & \multicolumn{2}{c}{ Region 2 } & \multicolumn{2}{c}{ Region 3 } & \multicolumn{2}{c}{ Average } \\
\cline { 2 - 9 } & IBS & HHR & IBS & HHR & IBS & HHR & IBS & HHR \\
\hline S24 & $0 \mathrm{a}$ & $0 \mathrm{~b}$ & $6.67 \mathrm{a}$ & $6.67 \mathrm{a}$ & $0 \mathrm{a}$ & $0 \mathrm{a}$ & 2.22 & 2.22 \\
S25 & $6.67 \mathrm{a}$ & $0 \mathrm{~b}$ & $6.67 \mathrm{a}$ & $10 \mathrm{a}$ & $0 \mathrm{a}$ & $0 \mathrm{a}$ & 4.44 & 3.33 \\
S26 & $0 \mathrm{a}$ & $0 \mathrm{~b}$ & $6.67 \mathrm{a}$ & $0 \mathrm{a}$ & $0 \mathrm{a}$ & $0 \mathrm{a}$ & 2.22 & 0 \\
S27 & $13.33 \mathrm{a}$ & $0 \mathrm{~b}$ & $6.67 \mathrm{a}$ & $0 \mathrm{a}$ & $0 \mathrm{a}$ & $0 \mathrm{a}$ & 6.67 & 0 \\
S28 & $6.67 \mathrm{a}$ & $0 \mathrm{~b}$ & $0 \mathrm{a}$ & $0 \mathrm{a}$ & $0 \mathrm{a}$ & $0 \mathrm{a}$ & 2.22 & 0 \\
S29 & $0 \mathrm{a}$ & $0 \mathrm{~b}$ & $6.67 \mathrm{a}$ & $6.67 \mathrm{a}$ & $0 \mathrm{a}$ & $0 \mathrm{a}$ & 2.22 & 2.22 \\
S30 & $0 \mathrm{a}$ & $0 \mathrm{~b}$ & $0 \mathrm{a}$ & $0 \mathrm{a}$ & $0 \mathrm{a}$ & $0 \mathrm{a}$ & 0 & 0 \\
S31 & $0 \mathrm{a}$ & $0 \mathrm{~b}$ & $0 \mathrm{a}$ & $0 \mathrm{a}$ & $0 \mathrm{a}$ & $0 \mathrm{a}$ & 0 & 0 \\
S32 & $0 \mathrm{a}$ & $13.33 \mathrm{~b}$ & $6.67 \mathrm{a}$ & $0 \mathrm{a}$ & $0 \mathrm{a}$ & $0 \mathrm{a}$ & 2.22 & 4.44 \\
S33 & $6.67 \mathrm{a}$ & $26.67 \mathrm{a}$ & $6.67 \mathrm{a}$ & $6.67 \mathrm{a}$ & $6.67 \mathrm{a}$ & $26.67 \mathrm{a}$ & 6.67 & 20 \\
S34 & $0 \mathrm{a}$ & $0 \mathrm{~b}$ & $0 \mathrm{a}$ & $6.67 \mathrm{a}$ & $6.67 \mathrm{a}$ & $13.33 \mathrm{~b}$ & 2.22 & 6.67 \\
S35 & $0 \mathrm{a}$ & $0 \mathrm{~b}$ & $0 \mathrm{a}$ & $0 \mathrm{a}$ & $6.67 \mathrm{a}$ & $0 \mathrm{a}$ & 2.22 & 0 \\
\hline
\end{tabular}

*: Means followed by common letters in the column are not significantly different at the $5 \%$ level by DMRT.

In region 2, the potato lines S2, S4, S5, and S18 showed a high rate of internal brown spots (13.33\%); and S6, S7, S9, S10, S11, S17, S19, S22, S23, S28, S30, and S31 were found to have high tolerance to it. On the other hand, potato lines other than S3, S7, S10, S14, S15, S17, and S23 were found to have tolerance in region 3 (Pyeong-chang). In the case of average of the three regions, potato lines S1, S6, S9, S19, S30, and S31 were found to be free from internal brown spots. However, internal brown spot occurrence rate is not significantly different in each region.

The highest number of internal brown spot resistant cultivars were recorded in Pyeong-chang (25), followed by Chuncheon (20) and Yang-gu (13). High temperature, along with fluctuating moisture content and Ca deficiency, can lead to a decline in tuber quality-internal brown spots and hollow hearts $[28,37,38]$. Our findings also deduce a higher internal brown spot rate in Yang-gu due to the presence of a lower concentration of Ca in soil (Table S1).

\subsection{Hollow Heart Rate (\%)}

Hollow heart is a physiological disorder and arises when the potato plant recovers too quickly from a period of environmental or nutritional stress. This disorder makes the tubers unattractive, and in severe case can also reduce the quality of chip processing potatoes [39]. In the present study, the rate of hollow heart differed among the cultivars. In region 1 (Chuncheon), potato line S32 showed the highest rate of hollow heart symptom (13.33\%), followed by that of S1, S2, S4, S6, S8, and S18 ( $\leq 7 \%)$. However, it can be considered as a low occurrence rate with $P<0.05$, compared to the control variety Atlantic $(26.67 \%)$ (Table 2).

In region 2, out of the 35 evaluated potato lines, S3, S16, S24, and S29 showed a comparatively higher hollow heart rate (6.67\%); however, most of the lines were found as tolerant as the control cultivar Superior. In the case of region 3, most of the potato lines showed strong tolerance to hollow heart symptoms, except S1, S6, S9, and S10, although these four clones performed better than the controls Atlantic and Shepody $(P<0.05)$. A total of 16 cultivars, including 2 controls, were found to be affected by hollow heart in an average of all three regions among the evaluated potato lines.

\subsection{Specific Gravity}

The potato clones also varied with respect to specific gravity (Table 3) and it ranged from 1.097 to 1.0321 in the Chuncheon (region 1) area. The clones S30 (1.097), S29 (1.085), S32 (1.084), and S24 (1.082) performed better than the others with $P<0.05$, while five other cultivars (S23, S31, S28, S19, S17, and S26) showed a similar trend, with significantly higher specific gravity levels compared to the three control varieties-Atlantic (1.0592), Shepody (1.0704), and Superior (1.0509). 
Table 3. Specific gravity (SG) and chip lightness (CL) of 35 potato lines grown in three different agro-ecological regions in South Korea.

\begin{tabular}{|c|c|c|c|c|c|c|c|c|}
\hline \multirow{2}{*}{ Lines } & \multicolumn{2}{|c|}{ Region 1} & \multicolumn{2}{|c|}{ Region 2} & \multicolumn{2}{|c|}{ Region 3} & \multicolumn{2}{|c|}{ Average } \\
\hline & SG & CL & SG & CL & SG & $\mathrm{CL}$ & SG & CL \\
\hline S1 & $1.03 *$ & 64.06 hijk & $1.07 \mathrm{abc}$ & $67 \mathrm{ab}$ & 1.07 bcdef & $65.08 \mathrm{def}$ & 1.06 & 65.38 \\
\hline $\mathrm{S} 2$ & 1.06 cdefgh & 67.83 cdef & $1.08 \mathrm{ab}$ & 63.39 cdef & $1.08 \mathrm{ab}$ & $65.61 \mathrm{de}$ & 1.07 & 65.61 \\
\hline S3 & 1.04 ghijkl & $65.81 \mathrm{fgh}$ & 1.035 jk & $63.29 \mathrm{cdef}$ & 1.07 bcde & $64.17 \mathrm{efg}$ & 1.05 & 64.42 \\
\hline S4 & $1.03 \mathrm{jkl}$ & 55.7 1op & 1.04 hijk & $56.01 \mathrm{kl}$ & 1.07 bcde & $54.76 \mathrm{k}$ & 1.05 & 55.49 \\
\hline S5 & 1.05 defghij & $66.57 \mathrm{efg}$ & 1.05 defghij & $58.94 \mathrm{ij}$ & $1.05 \mathrm{fg}$ & $60.11 \mathrm{i}$ & 1.05 & 61.87 \\
\hline S6 & 1.05 defghij & $62.55 \mathrm{jklmn}$ & 1.06 abcdef & 63.35 cdef & 1.07 bcdef & $64.14 \mathrm{efg}$ & 1.06 & 63.35 \\
\hline S7 & 1.06 cdefgh & $60.35 n$ & 1.06 bcdefg & $64.34 \mathrm{~cd}$ & 1.07 bcdef & $62.73 \mathrm{fgh}$ & 1.06 & 62.47 \\
\hline S8 & 1.05 efghijk & 64.79 ghij & 1.05 fghijk & $53.01 \mathrm{~m}$ & $1.05 \mathrm{fg}$ & $56.8 \mathrm{jk}$ & 1.05 & 58.2 \\
\hline S9 & 1.05 fghijkl & 68.25 bcde & $1.07 \mathrm{abcd}$ & $68.31 \mathrm{a}$ & 1.06 bcdef & $68.52 \mathrm{bc}$ & 1.06 & 68.36 \\
\hline S10 & $1.04 \mathrm{ijkl}$ & 67.87 cdef & 1.071 abcdef & $64.98 \mathrm{bcd}$ & 1.06 bcdef & $68.26 \mathrm{bc}$ & 1.06 & 67.04 \\
\hline S11 & $1.04 \mathrm{jkl}$ & $71.95 \mathrm{a}$ & 1.04 ghijk & $65.08 \mathrm{bcd}$ & $1.06 \mathrm{cdef}$ & $65.16 \mathrm{def}$ & 1.05 & 67.4 \\
\hline S12 & $1.04 \mathrm{ijkl}$ & 64.68 ghij & 1.05 fghijk & 64.19 cde & 1.07 bcde & $62.17 \mathrm{ghi}$ & 1.05 & 63.68 \\
\hline $\mathrm{S} 13$ & 1.05 defghij & $65.44 \mathrm{ghi}$ & 1.05 efghij & $64.91 \mathrm{bcd}$ & 1.07 bcdef & $62.99 \mathrm{fgh}$ & 1.06 & 64.45 \\
\hline S14 & $1.03 \mathrm{kl}$ & $69.41 b c$ & $1.04 \mathrm{ijk}$ & $65.49 \mathrm{bc}$ & $1.04 \mathrm{~g}$ & $66.7 \mathrm{~cd}$ & 1.03 & 67.2 \\
\hline S15 & 1.05 defghij & 63.74 hijk & 1.05 fghijk & $63.81 \mathrm{cdef}$ & 1.07 bcdef & 64.51 defg & 1.06 & 64.02 \\
\hline S16 & 1.04 hijkl & 64.86 ghij & 1.04 ghijk & $65.71 \mathrm{bc}$ & 1.07 bcde & $66.68 \mathrm{~cd}$ & 1.05 & 65.75 \\
\hline S17 & 1.07 bcdefg & $42.02 \mathrm{q}$ & 1.06 abcdef & $41.92 \mathrm{o}$ & 1.08 bcde & $41.97 \mathrm{~m}$ & 1.07 & 41.97 \\
\hline S18 & 1.06 bcdefg & $57.75 \mathrm{o}$ & $1.07 \mathrm{abcd}$ & $65.57 \mathrm{bc}$ & 1.07 bcdef & $69.35 \mathrm{~b}$ & 1.07 & 64.22 \\
\hline S19 & 1.07 bcdefg & $60.5 n$ & 1.07 abcde & $65.59 \mathrm{bc}$ & 1.07 bcde & $62.82 \mathrm{fgh}$ & 1.07 & 62.97 \\
\hline S20 & 1.06 cdefghi & $70.31 \mathrm{ab}$ & $1.08 \mathrm{ab}$ & $68.98 \mathrm{a}$ & 1.06 ef & 66.34 cde & 1.06 & 68.54 \\
\hline $\mathrm{S} 21$ & 1.031 & $63.15 \mathrm{ijklm}$ & $1.02 \mathrm{k}$ & $64.71 \mathrm{bcd}$ & 1.06 bcdef & 66.14 cde & 1.04 & 64.67 \\
\hline S22 & 1.06 bcdefg & $57.08 \mathrm{o}$ & 1.07 abcdef & $58.09 \mathrm{jk}$ & 1.07 bcdef & $60 \mathrm{i}$ & 1.07 & 58.39 \\
\hline S23 & $1.07 \mathrm{abcd}$ & $53.99 \mathrm{p}$ & $1.08 \mathrm{a}$ & $55.09 \mathrm{~lm}$ & 1.07 bcdef & $57.19 \mathrm{j}$ & 1.07 & 55.42 \\
\hline S24 & $1.08 \mathrm{abc}$ & $68.99 \mathrm{bcd}$ & $1.08 \mathrm{a}$ & $68.78 \mathrm{a}$ & $1.10 \mathrm{a}$ & $71.77 \mathrm{a}$ & 1.09 & 69.85 \\
\hline S25 & 1.07 bcdef & $61.43 \mathrm{lmn}$ & $1.08 \mathrm{ab}$ & 59.33 hij & $1.08 \mathrm{abc}$ & $63.03 \mathrm{fgh}$ & 1.08 & 61.26 \\
\hline S26 & 1.07 bcdefg & $43.33 \mathrm{q}$ & 1.06 bcdefgh & $50.23 n$ & $1.06 \mathrm{def}$ & 50.161 & 1.06 & 47.91 \\
\hline S27 & 1.05 fghijk & $60.8 \mathrm{mn}$ & 1.05 defghij & 60.77 ghi & 1.08 bcde & $60.74 \mathrm{hi}$ & 1.06 & 60.77 \\
\hline S28 & 1.07 abcde & $60.49 n$ & 1.07 abcde & 60.74 ghi & 1.07 bcde & 60.99 hi & 1.07 & 60.74 \\
\hline S29 & $1.08 \mathrm{ab}$ & $41.28 \mathrm{q}$ & 1.07 abcde & 63.14 cdef & 1.06 bcdef & $62.81 \mathrm{fgh}$ & 1.07 & 55.74 \\
\hline S30 & $1.09 \mathrm{a}$ & $60.88 \mathrm{mn}$ & $1.08 \mathrm{a}$ & $62.11 \mathrm{efg}$ & 1.08 bcde & $63.03 \mathrm{fgh}$ & 1.08 & 62.01 \\
\hline S31 & 1.07 abcde & $60.4 \mathrm{n}$ & $1.07 \mathrm{abc}$ & $61.42 \mathrm{fgh}$ & 1.06 bcdef & $62.98 \mathrm{fgh}$ & 1.07 & 61.6 \\
\hline S32 & $1.08 \mathrm{ab}$ & $61.84 \mathrm{klmn}$ & $1.07 \mathrm{abc}$ & $62.63 \mathrm{defg}$ & 1.07 bcde & $60.23 \mathrm{i}^{\circ}$ & 1.08 & 61.57 \\
\hline S33 & 1.05 defghij & $69.03 \mathrm{bcd}$ & 1.05 cdefghi & $68.34 \mathrm{a}$ & 1.07 bcde & $68.07 \mathrm{bc}$ & 1.06 & 68.48 \\
\hline S34 & 1.07 bcdefg & 66.98 defg & $1.07 \mathrm{abcd}$ & $67.99 \mathrm{a}$ & 1.07 bcde & $68.07 \mathrm{bc}$ & 1.07 & 67.68 \\
\hline S35 & 1.05 ghijkl & $63.2 \mathrm{ijklm}$ & $1.04 \mathrm{ijk}$ & $64.1 \mathrm{cde}$ & $1.08 \mathrm{abcd}$ & 64.72 def & 1.05 & 64.01 \\
\hline
\end{tabular}

*: Means followed by a common letter in the column are not significantly different at the $5 \%$ level by DMRT.

In the case of region 2 (Yang-gu), potato lines S23 and S24 showed a higher specific gravity (1.089) among the evaluated lines with $P<0.05$, while 16 other clones and 1 control (Shepody) were found with similar results, with significant higher specific gravity levels compared to control varieties Atlantic and Superior. S24 was also found to be better with high specific gravity (1.103) in region 3 (Pyeong-chang) compared to all three control varieties.

The observed differences in specific gravity among potato clones may be due to genetic and environmental factors, since all clones were grown and tested in three different locations. Pyeong-chang exhibited higher specific gravity compared to the other two locations. In a previous study, it was observed that potato clones with high specific gravity exhibited high dry matter content, which is an important feature in the selection for chips processing [40]. The tuber processing industry often uses a specific gravity for quick estimation of total solids, as these two parameters are considered highly correlated to each other [41,42]. Favorable soil type with low temperature, rainfall and sunshine during maturing time may be a reason for high production of tubers with higher specific gravity in the Pyeong-chang area. 


\subsection{Chip Lightness}

Significant $(P<0.05)$ variations in chip lightness of potatoes were observed among the cultivars in different locations. Chip lightness ranged from 71.95-41.28, 68.31-41.92, and 68.31-41.92 in region 1 (Chuncheon), region 2 (Yang-gu), and region 3 (Pyeong-chang), respectively (Table 3). The potato lines S11 and S20 performed better than all of the three control cultivars with $P<0.05$ in Chuncheon; S20 was found to perform better in Yang-gu, while other clones like S1, S9, and S24 showed a similar trend, including the control varieties of Atlantic (68.34) and Shepody (67.99). On the other hand, S24 performed better than all the other clones, including the three controls varieties, in both Pyeong-chang and average of the three regions.

Based on a correlation test performed in the study, it can be clearly stated that the higher the glucose contents, the lower the chip lightness is in potato lines S3, S8, S11, S16, S19, S25, and S26; similarly, the lower the glucose content, the higher is the chip lightness in S2, S7, S9, S10, S14, S18, S24, and S31 (Figures 4 and 5). The color and taste of the chips mainly depend on the amount of reducing sugar (glucose and fructose) present in potato tubers. Sucrose hydrolyses occurs after harvest by vacuolar acid invertase, resulting in accumulation of glucose and fructose [43-45]. During frying, a nonenzymatic Maillard reaction takes place by a reaction between reducing sugar and free amino acids that produce dark-colored, bitter-tasting products [46,47]. In general, higher glucose content $(>0.2 \%)$ in processing potatoes that produce a darker chip are considered to be of low quality. Meena et al. and Hayes and Thill $[48,49]$ have stated that 'tubers have low levels of reducing sugars and produce light-colored chips directly after harvest'. Among the evaluated potato lines, a total of 11 lines showed high glucose content in the fresh tuber.

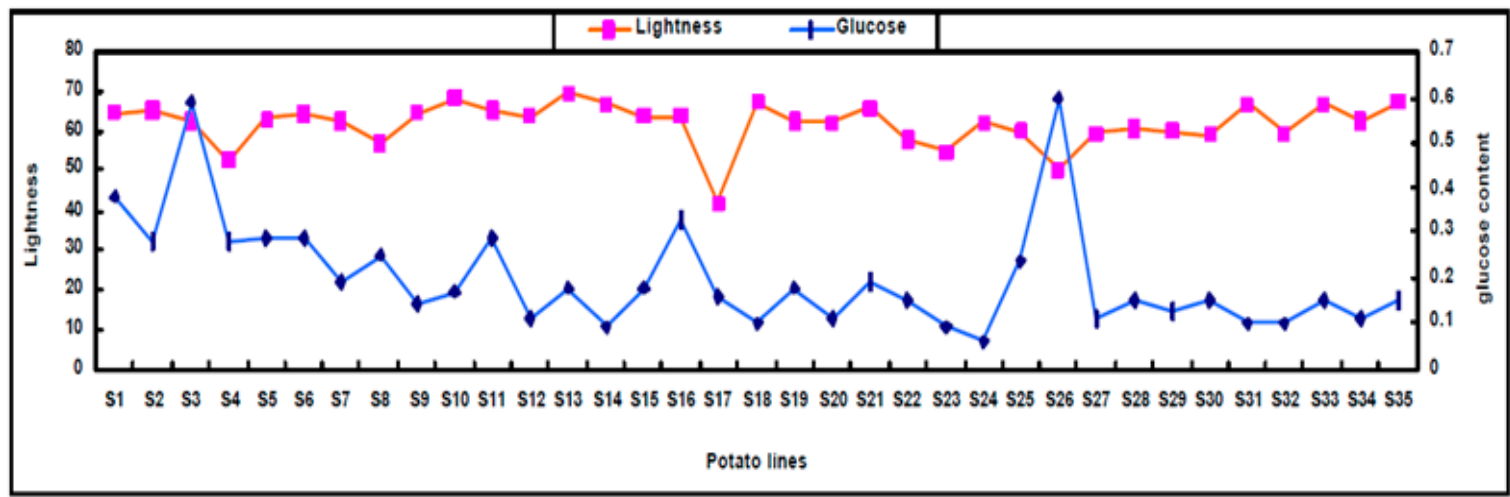

Figure 4. Correlation between chip lightness and glucose content of 35 potato lines harvested in Yang-gu, South Korea.

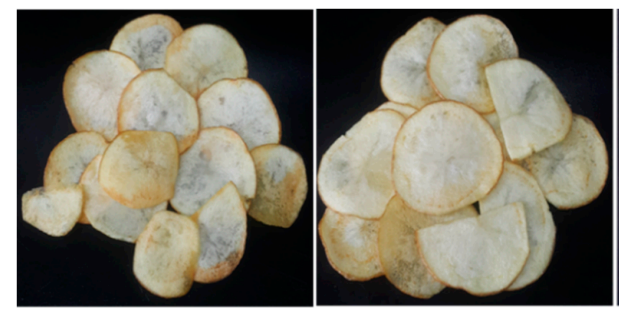

JuiceValley

GangwonValley

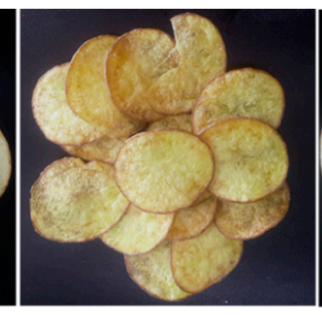

Rose Valley

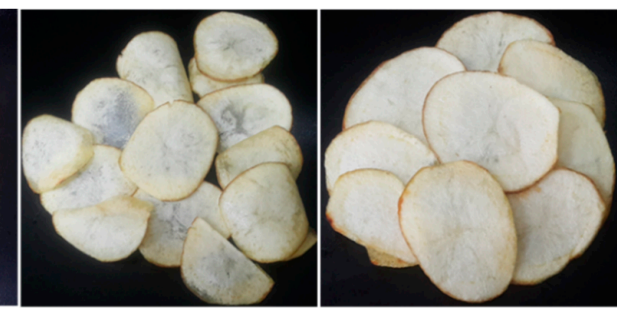

Valley 43
Valley 91

Figure 5. Fried chips of select potato lines.

\section{Conclusions}

In this study, both tuber yield and marketable rate were seen as varied under agro-ecological conditions. The results showed that Pyeong-chang, a high-altitude region with longer maturation time, is more suitable for producing high tuber yield and marketable tuber rate (\%) than the other two regions. Despite a high rate of common scab, most of the cultivars showed high processing quality, 
especially specific gravity. Although physiological disorders like cracking, hollow heart, and internal brown spot were common in all three areas, most of the evaluated lines had high processing quality. Despite a lower internal brown spot and hollow heart in the Pyeong-chang area, regional variation for other physiological disorders were not clear.

Specific gravity was also found to be higher in the Pyeong-chang area, but chip lightness was not affected by environmental conditions. It seems that dark colouring in chip quality may be due to a high content of glucose in potato. Compared to the three control cultivars (Atlantic, Shepody, and Superior), the results showed that the genotypes S10, S11, S13, and S32 in Chuncheon; S13, S24, and S32 in Yang-gu, and S24, S30, and S32 in Pyeong-chang recorded high marketable quality, and lower infection rates and physiological disorders. It was also observed that higher chip lightness was obtained from S2, S10, S18, S24, and S31 among the high-yielding genotypes. In addition, despite a high occurrence rate of common scab, the Pyeong-chang area was found to be suitable for potato chip processing. The above research shows that high-altitude areas are comparatively more suitable for the production of high quality products, especially for potato chip processing.

Supplementary Materials: The following are available online at http://www.mdpi.com/2077-0472/10/8/327/s1, Table S1: Soil condition at R1 (Chuncheon), R2 (Yang-gu) and R3 (Pyeong-chang), Figure S1: Mean temperature, rainfall, and hour of sunshine at Chun-cheon (the top), Yang-gu (the middle), and Pyeong-chang (the bottom) from 2016 to 2018 growing season.

Author Contributions: J.I., S.P.C., and J.W.K. conceived and designed the experiments, carried out the experimental works; collected, analyzed the data; and drafted the final manuscript. O.K.A. read and improved the manuscript. Y.-S.L. validated all the protocols and supervised the study. All authors have read and agreed to the published version of the manuscript.

Funding: This research did not receive any specific grant.

Conflicts of Interest: The authors declare no conflict of interest.

\section{References}

1. Hijmans, R.J.; Spooner, D.M. Geographic distribution of wild potato species. Am. J. Bot. 2001, 88, 2101-2112. [CrossRef] [PubMed]

2. Statistics Korea. Available online: http://kostat.go.kr/portal/eng/surveyOutline/1/5/index.static (accessed on 1 May 2020).

3. Zhang, H.; Fen, X.; Yu, W.; Hu, H.; Dai, X. Progress of potato staple food research and industry development in China. J. Integr. Agric. 2017, 16, 2924-2932. [CrossRef]

4. Ek, K.L.; Wang, S.; Copeland, L.; Brand-Miller, J.C. Discovery of a low-glycaemic index potato and relationship with starch digestion in vitro. Br. J. Nutr. 2014, 111, 699-705. [CrossRef] [PubMed]

5. Camire, M.E.; Kubow, S.; Donnelly, D.J. Potatoes and human health. Crit. Rev. Food Sci. Nutr. 2009, 49, 823-840. [CrossRef]

6. Visvanathan, R.; Jayathilake, C.; Chaminda Jayawardana, B.; Liyanage, R. Health-beneficial properties of potato and compounds of interest. J. Sci. Food Agric. 2016, 96, 4850-4860. [CrossRef]

7. Lovat, C.; Nassar, A.M.K.; Kubow, S.; Li, X.-Q.; Donnelly, D.J. Metabolic biosynthesis of potato (Solanum tuberosum L.) antioxidants and implications for human health. Crit. Rev. Food Sci. Nutr. 2016, 56, 2278-2303. [CrossRef]

8. Friedman, M. Nutritional value of proteins from different food sources. A review. J. Agric. Food Chem. 1996, 44, 6-29. [CrossRef]

9. Ezekiel, R.; Singh, N.; Sharma, S.; Kaur, A. Beneficial phytochemicals in potato-A review. Food Res. Int. 2013, 50, 487-496. [CrossRef]

10. Bach, S.; Yada, R.Y.; Bizimungu, B.; Sullivan, J.A. Genotype by environment interaction effects on fibre components in potato (Solanum tuberosum L.). Euphytica 2012, 187, 77-86. [CrossRef]

11. Potato Production Worldwide, 2018|Statista. Available online: https://www.statista.com/statistics/382174/ global-potato-production/ (accessed on 1 May 2020). 
12. Birch, P.R.J.; Bryan, G.; Fenton, B.; Gilroy, E.M.; Hein, I.; Jones, J.T.; Prashar, A.; Taylor, M.A.; Torrance, L.; Toth, I.K. Crops that feed the world 8: Potato: Are the trends of increased global production sustainable? Food Secur. 2012, 4, 477-508. [CrossRef]

13. Carputo, D.; Aversano, R.; Frusciante, L. Breeding potato for quality traits. Acta Hortic. 2005, 684, 55-64. [CrossRef]

14. Sverrisdóttir, E.; Byrne, S.; Sundmark, E.H.R.; Johnsen, H.Ø.; Kirk, H.G.; Asp, T.; Janss, L.; Nielsen, K.L. Genomic prediction of starch content and chipping quality in tetraploid potato using genotyping-by-sequencing. Theor. Appl. Genet. 2017, 130, 2091-2108. [CrossRef] [PubMed]

15. Dale, M.E.B.; Mackay, G.R. Inheritance of table and processing quality, in Bradshaw. In Potato Genetics; Bradshaw, J.E., Mackay, G.R., Eds.; CABI: Wallingford, UK, 1994; pp. 285-315.

16. Colman, S.L.; Massa, G.A.; Carboni, M.F.; Feingold, S.E. Cold sweetening diversity in Andean potato germplasm from Argentina. J. Sci. Food Agric. 2017, 97, 4744-4749. [CrossRef] [PubMed]

17. Hamernik, A.J.; Hanneman, R.E.; Jansky, S.H. Introgression of wild species germplasm with extreme resistance to cold sweetening into the cultivated potato. Crop Sci. 2009, 49, 529-542. [CrossRef]

18. Rana, R.K.; Pandey, S.K. Processing quality potatoes in India: An estimate of industry's demand. Proc. Food Ind. 2007, 10, 26-35.

19. Harris, P.M. Mineral nutrition. In The Potato Crop; Springer: Berlin/Heidelberg, Germany, 1992; pp. $162-213$.

20. Horsfall, J.G. An improved grading system for measuring plant diseases. Phytopathology 1945, 35, 655.

21. Mihovilovich, E.; Carli, C.; Mendiburu, F.; de Hualla, V.; Bonierbale, M. Tuber Bulking Maturity Assessment of Elite and Advanced Potato Clones Protocol; International Potato Center (CIP): Lima, Peru, 2014; 43p, ISBN 978-92-9060-441-9.

22. Patel, H.R.; Shekh, A.M.; Pate, G.C.; Mistry, D.S. Yield and quality of potato in relation to different dates of planting. J. Indian Potato Assoc. 2000, 27, 87-90.

23. Sojka, R.E.; Westermann, D.T.; Kincaid, D.C.; McCann, I.R.; Halderson, J.L.; Thornton, M. Zone-subsoiling effects on potato yield and grade. Am. Potato J. 1993, 70, 475-484. [CrossRef]

24. Singh, N.; Ahmed, Z. Effect of mulching on potato production in high altitude cold arid zone of Ladakh. Potato J. 2008, 35.

25. Kim, Y.-U.; Seo, B.-S.; Choi, D.-H.; Ban, H.-Y.; Lee, B.-W. Impact of high temperatures on the marketable tuber yield and related traits of potato. Eur. J. Agron. 2017, 89, 46-52. [CrossRef]

26. De Temmerman, L.; Wolf, J.; Colls, J.; Bindi, M.; Fangmeier, A.; Finnan, J.; Ojanperä, K.; Pleijel, H. Effect of climatic conditions on tuber yield (Solanum tuberosum L.) in the European 'CHIP'experiments. Eur. J. Agron. 2002, 17, 243-255. [CrossRef]

27. Kooman, P.L.; Fahem, M.; Tegera, P.; Haverkort, A.J. Effects of climate on different potato genotypes 1. Radiation interception, total and tuber dry matter production. Eur. J. Agron. 1996, 5, 193-205. [CrossRef]

28. Naumann, M.; Koch, M.; Thiel, H.; Gransee, A.; Pawelzik, E. The importance of nutrient management for potato production part II: Plant nutrition and tuber quality. Potato Res. 2020, 63, 121-137. [CrossRef]

29. Zotarelli, L.; Hutchinson, C.; Byrd, S.; Gergela, D.; Rowl, D.L. Potato Physiological Disorders-Growth Cracks; Horticultural Sciences Department, UF/IFAS Extension: Gainesville, FL, USA, 2003.

30. Zhang, S.-Y.; Li, X.-Y. Soil moisture and temperature dynamics in typical alpine ecosystems: A continuous multi-depth measurements-based analysis from the Qinghai-Tibet Plateau, China. Hydrol. Res. 2018, 49, 194-209. [CrossRef]

31. Braun, S.; Gevens, A.; Charkowski, A.; Allen, C.; Jansky, S. Potato common scab: A review of the causal pathogens, management practices, varietal resistance screening methods, and host resistance. Am. J. Potato Res. 2017, 94, 283-296. [CrossRef]

32. Clarke, C.R.; Kramer, C.G.; Kotha, R.R.; Wanner, L.A.; Luthria, D.L.; Kramer, M. Cultivar Resistance to Common Scab Disease of Potato Is Dependent on the Pathogen Species. Phytopathology 2019, 109, 1544-1554. [CrossRef]

33. Terman, G.L.; Steinmetz, F.H.; Hawkins, A. Effects of Certain Soil Conditions and Treatments upon Potato Yields and the Development and Control of Potato Scab; Maine Agricultural Experiment Station: Orono, ME, USA, 1948; Volume 463, p. 31.

34. Odland, T.E.; Allbritten, H.G. Soil reaction and calcium supply as factors influencing the yield of potatoes and the occurrence of scab. Agron. J. 1950, 42, 269-275. [CrossRef] 
35. Goto, K. Relationships between soil $\mathrm{pH}$, available calcium and prevalence of potato scab. Soil Sci. Plant Nutr. 1985, 31, 411-418. [CrossRef]

36. Tzeng, K.C.; Kelman, A.; Simmons, K.E.; Kelling, K.A. Relationship of calcium nutrition to internal brown spot of potato tubers and sub-apical necrosis of sprouts. Am. Potato J. 1986, 63, 87-97. [CrossRef]

37. Olsen, N.L.; Hiller, L.K.; Mikitzel, L.J. The dependence of internal brown spot development upon calcium fertility in potato tubers. Potato Res. 1996, 39, 165-178. [CrossRef]

38. Palta, J.P. Improving potato tuber quality and production by targeted calcium nutrition: The discovery of tuber roots leading to a new concept in potato nutrition. Potato Res. 2010, 53, 267-275. [CrossRef]

39. Elbatawi, I.E. An acoustic impact method to detect hollow heart of potato tubers. Biosyst. Eng. 2008, 100, 206-213. [CrossRef]

40. Wayumba, B.O.; Choi, H.S.; Seok, L.Y. Selection and evaluation of 21 potato (Solanum tuberosum) breeding clones for cold chip processing. Foods 2019, 8, 98. [CrossRef]

41. Grewal, S.S.; Uppal, D.S. Effect of dry matter and specific gravity on yield, colour and oil content of potato chips. Indian Food Pack. 1989, 43, 17-20.

42. Killick, R.J.; Simmonds, N.W. Specific gravity of potato tubers as a character showing small genotype-environment interactions. Heredity (Edinburgh) 1974, 32, 109-112. [CrossRef]

43. Wu, L.; Bhaskar, P.B.; Busse, J.S.; Zhang, R.; Bethke, P.C.; Jiang, J. Developing cold-chipping potato varieties by silencing the vacuolar invertase gene. Crop Sci. 2011, 51, 981-990. [CrossRef]

44. Chen, X.; Salamini, F.; Gebhardt, C. A potato molecular-function map for carbohydrate metabolism and transport. Theor. Appl. Genet. 2001, 102, 284-295. [CrossRef]

45. Wiberley-Bradford, A.E.; Bethke, P.C. Suppression of the vacuolar invertase gene delays senescent sweetening in chipping potatoes. J. Sci. Food Agric. 2018, 98, 354-360. [CrossRef]

46. Shallenberger, R.S.; Smith, O.; Treadway, R.H. Food color changes, role of the sugars in the browning reaction in potato chips. J. Agric. Food Chem. 1959, 7, 274-277. [CrossRef]

47. Kumar, D.; Singh, B.P.; Kumar, P. An overview of the factors affecting sugar content of potatoes. Ann. Appl. Biol. 2004, 145, 247-256. [CrossRef]

48. Meena, R.S.; Manivel, P.; Bharadwaj, V.; Gopal, J. Screening potato wild species for low accumulation of reducing sugars during cold storage. Electron. J. Plant Breed. 2009, 1, 89-92.

49. Hayes, R.J.; Thill, C.A. Selection for potato genotypes from diverse progenies that combine $4 \mathrm{C}$ chipping with acceptable yields, specific gravity, and tuber appearance. Crop Sci. 2002, 42, 1343-1349. [CrossRef] 